\title{
Pemanfaatan Tumbuhan Obat oleh Suku Togutil di Daerah Penyangga Taman Nasional Aketajawe Lolobata
}

\section{Medicinal Plant Utilization by the Togutil Tribe in the Buffer Zone of Aketajawe Lolobata National Park}

\author{
ROFIDAH UMMULHARBI APAL ${ }^{1}$, NUNIK SRI ARIYANTI ${ }^{*}$, EKO BAROTO WALUJO², \\ DORLY ${ }^{1}$
}

\author{
${ }^{1}$ Departemen Biologi, Fakultas Matemetika dan Ilmu Pengetahuan Alam, Institut Pertanian Bogor, Bogor, Indonesia \\ ${ }^{2}$ Pusat Penelitian Biologi LIPI. Cibinong Science Center, Bogor, Indonesia
}

Diterima 27 Agustus 2018 /Disetujui 11 Oktober 2018

\begin{abstract}
Togutil is an indigenous tribe that lives in buffer zone of the Aketajawe Lolobata National Park (ALNP) Halmahera Island, North Maluku. This tribe still uses medicinal plants to treat diseases and health care due to limited access to the modern health care. This study aimed to identify the biodiversity and utilization of medicinal plants, as well as to analyze the index of cultural significance of the medicinal plants based on the traditional knowledge of the Togutil tribe. This research was conducted from June to November 2016. The research was conducted in 3 villages by interviewing $3 \mathrm{key}$ informants and 36 respondents. The cultural significance of the medicinal plant species was analysis based on its quality, intencity, and exclusivity value. The result shows that the Togutil tribe use 69 species of medicinal plants for treating 45 categories of diseases. They are mostly used as medicine are leaves (43 species). There are several ways to use the medicinal plants, including smearing, dripping, in taking per oral and per nasal. Gluta renghas is the most important.
\end{abstract}

Key words: Togutil, Medicinal plants, Halmahera, North Maluku

\section{PENDAHULUAN}

Togutil adalah sebutan untuk suku pedalaman yang bermukim di kawasan hutan Pulau Halmahera Maluku Utara. Sebagian dari masyarakat suku Togutil masih hidup secara berpindah-pindah (nomaden) di dalam hutan dan ada yang telah menetap di suatu pemukiman sekitar hutan. Mata pencaharian suku Togutil nomaden adalah berburu dan berladang berpindah, sedangkan pekerjaan suku Togutil yang sudah menetap adalah berkebun (petani kopra), beberapa ada yang memiliki usaha sampingan seperti menjual batu kali (Nurrani dan Tabba 2013).

Layaknya masyarakat pedalaman lainnya di Indonesia yang jauh dari perkembangan modernisasi, suku Togutil masih menghadapi masalah terhadap akses pelayanan kesehatan modern. Walaupun sejauh ini pemerintah telah berupaya membangun fasilitasfasilitas pelayanan kesehatan seperti Rumah sakit dan Puskesmas, serta menempatkan tenaga-tenaga medis seperti dokter, mantri dan bidan di ibukota kecamatan, namun belum dapat menjangkau mereka. Kondisi tersebut dihadapi orang-orang Togutil dengan tetap memanfaatkan tumbuh-tumbuhan di

\footnotetext{
*Penulis korespondensi:

E-mail: nuniksa@gmail.com
}

sekitar hutan tempat pemukiman mereka untuk obatobatan (Rahman 2013). Ketergantungan suku Togutil pada sumber daya alam melahirkan pengetahuan pemanfaatan sumberdaya alam yang diwariskan secara turun-temurun dari generasi ke generasi dan akhirnya terakumulasi menjadi kearifan lokal. Penelitian Karim et al. (2006) melaporkan bahwa masyarakat Togutil mengetahui dan memanfaatkan 49 jenis tumbuhan sebagai bahan obat. Umumnya pengetahuan pengobatan tradisional hanya dikuasai oleh kaum tua. Generasi muda saat ini kurang termotivasi untuk menggali pengetahuan dari kaum tua. Lambat laun kondisi seperti ini menjadikan warisan tradisional mengalami kepunahan di tempat aslinya (Noorcahyati 2012). Di sisi lain memudarnya pengetahuan tentang pemanfaatan tumbuhan obat ini disebabkan oleh kurangnya sosialisasi yang dilakukan oleh generasi tua dalam masyarakat Togutil terhadap generasi muda dan adanya perubahan pola hidup dilingkungan sekitar tempat pemukiman masyarakat Togutil seperti adanya interaksi mereka dengan warga transmigrasi. Oleh karena itu, keanekaragaman tumbuhan obat dan pemanfaatannya dalam sistem pengetahuan tradisional yang dimiliki oleh masyarakat Togutil ini perlu didokumentasikan, dan dikaji lanjut secara ilmiah. Salah satu upaya untuk mendokumentasikan pengetahuan tersebut adalah 
melalui kajian etnobotani tumbuhan berkhasiat obat yang dikenal dengan istilah etnomedisin (Karim et al. 2006). Pengetahuan tentang tumbuhan obat yang digunakan secara tradisional ini dapat dijadikan sumber acuan untuk mengembangkan sistem pengobatan modern dari hasil ekstraksi tumbuhtumbuhan tersebut. Penelitian ini bertujuan untuk mengidentifikasi keanekaragaman tumbuhan obat serta pemanfaatannya berdasarkan pengetahuan tradisional masyarakat Togutil yang sudah menetap di daerah penyangga Taman Nasional Aketajawe Lolobata serta menghitung nilai kepentingan budaya keanekaragaman jenis tumbuhan obat tersebut.

\section{BAHAN DAN METODE}

Lokasi dan Waktu Penelitian. Penelitian ini dilakukan di daerah penyangga Taman Nasional Aketajawe Lolobata Halmahera Timur Maluku Utara, pada bulan Juni hingga November 2016. Objek kajian dilakukan terhadap suku Togutil yang telah menetap di 3 desa yaitu, Oboy, Tukur-tukur, dan Totodoku yang merupakan anak desa di Kecamatan Wasile Timur Maluku Utara.

Pengumpulan Data, Pemilihan Informan dan Responden. Pengumpulan data dilakukan dengan wawancara pada masyarakat di masing-masing desa yang dibagi menjadi informan kunci dan responden. Jumlah informan adalah 1 orang di tiap desa, sehingga total informan kunci adalah 3 orang. Informan kunci yang dipilih adalah tetua atau dukun yang memiliki pengetahuan mengenai tumbuhan obat dan sistem pengobatan di tiap desa tersebut. Adapun responden ditentukan mewakili variabel demografi yakni jenis kelamin dan kelompok umur. Pada masing-masing desa dipilih 12 orang yang terdiri atas 6 laki-laki dan 6 perempuan berusia lebih dari 16 tahun. Wawancara dilakukan untuk memperoleh data nama jenis tumbuhan obat yang dimanfaatkan, jenis pemanfaatannya atau penyakit yang diobati, bagian tumbuhan yang dimanfaatkan, serta cara pengolahannya sebagai bahan obat. Selain itu, pada tahapan wawancara ini informan kunci dan responden juga diminta untuk memberikan penilaian (skor) berdasarkan nilai kualitas, intensitas dan eksklusifitas kegunaan dari masing-masing tumbuhan obat yang digunakan.

Analisis Data. Data nilai kualitas, intensitas, dan eksklusifitas digunakan untuk menghitung indeks nilai kepentingan budaya (Index of Cultural Significanse/ICS) berdasarkan pada rumus ICS $=\mathrm{q}$ x i x e mengikuti Turner (1998) dengan modifikasi keterangan komponen q, i, dan e berikut ini.

Keterangan :

q : nilai kualitas, yaitu nilai kegunaan suatu jenis tumbuhan; dengan memberi nilai $3=$ untuk bahan obat utama, nilai 2 = untuk bahan obat utama dan bahan obat tambahan, $1=$ untuk bahan ritual dan mitos. i : nilai intensitas, menggambarkan intensitas kegunaan dari suatu jenis tumbuhan dengan pemberian nilai $4=$ nilai intensitas penggunaan sangat tinggi ( 1 bulan), $3=$ intensitas penggunaan tinggi ( \pm 6 bulan), $2=$ untuk intensitas penggunaan sedang ( \pm 1 tahun), $1=$ intensitas penggunaan rendah ( $>1$ tahun).

e : nilai eksklusivitas, nilai pilihan penggunaan dengan memberi nilai 2 = paling disukai dan merupakan pilihan utama, 1 = pilihan cadangan (kemungkinan) bila terdapat beberapa jenis yang kemungkinan menjadi pilihan.

\section{HASIL}

Keanekaragaman Jenis Tumbuhan Obat. Keanekaragaman jenis tumbuhan yang dimanfaatkan sebagai tumbuhan obat (TO) oleh masyarakat suku Togutil adalah sebanyak 69 jenis tumbuhan. Jenis-jenis tumbuhan obat ini termasuk ke dalam 40 famili dan satu jenis tumbuhan obat tidak teridentifikasi nama marga dan familinya. Masing-masing famili memiliki satu hingga lima jenis tumbuhan yang digunakan sebagai obat tradisional pada suku Togutil. Tumbuhan obat 3-5 jenis dijumpai pada Euphorbiaceae, Zingiberaceae, Malvaceae, Solanaceae, Arecaceae, serta Lamiaceae (Tabel 1).

Kategori penyakit dan jumlah tumbuhan obat. Jenis-jenis penyakit dan perawatan kesehatan dalam istilah lokal suku Togutil dapat dimasukkan dalam 45 kategori istilah baku penyakit berdasarkan standarisasi RISTOJA (2017), tetapi ada 3 jenis penyakit tidak ada istilah bakunya (Tabel 2). Penggunaan untuk perawatan pra dan pasca melahirkan merupakan jenis penggunaan tumbuhan yang memanfaatkan jenis-jenis tumbuhan obat yang lebih beragam. Sebanyak 14 jenis tumbuhan obat digunakan untuk perawatan pra dan pasca melahirkan, terdiri atas 7 jenis tumbuhan yang digunakan sebagai obat tunggal dan 7 jenis lainnya sebagai obat ramuan. Empat jenis tumbuhan obat yang berbeda digunakan penyakit kelamin dan 3 jenis tumbuhan untuk menyembuhkan demam. Pengobatan penyakit lainnya hanya menggunakan satu jenis tumbuhan obat.

Hasil penelitian menunjukan bahwa masyarakat Togutil dalam mengobati suatu jenis penyakit lebih sering menggunakan bahan obat tunggal, hanya dari satu jenis tumbuhan. Pengobatan dengan meramu beberapa jenis tumbuhan obat lebih jarang dilakukan. Obat ramuan hanya dijumpai pada pengobatan hernia dan cedera tulang, serta perawatan pra dan pasca melahirkan.

Kategori bagian yang dimanfaatkan dan cara pemanfaatannya. Bahan obat yang digunakan oleh Suku Togutil dapat berupa seluruh bagian tumbuhan, atau bagian tumbuhan seperti rimpang, akar, batang, kulit batang, cabang muda, daun, buah, dan biji. Pengobatan penyakit oleh Suku Togutil lebih umum menggunakan bahan obat dari daun. Ada 43 jenis tumbuhan obat yang daunnya digunakan sebagai bahan 
Tabel 1. Keanekaragaman tumbuhan obat yang digunakan Suku Togutil

\begin{tabular}{|c|c|c|}
\hline Famili & Marga & Nama ilmiah, nama daerah \\
\hline \multirow[t]{3}{*}{ Euphorbiaceae } & Euphorbia & $\begin{array}{l}\text { Euphorbia heterophylla (Kastroli), Euphorbia sp. (Sondo-sondo), Euphorbia tirucalli } \\
\text { (Pohong tulang) }\end{array}$ \\
\hline & Jatropha & Jatropha curcas (Balacai) \\
\hline & Mallotus & Mallotus peltatus (Kayu Bifi /Pea-pea) \\
\hline \multirow[t]{5}{*}{ Zingiberaceae } & Alpinia & Alpini a galanga (Halia) \\
\hline & Curcuma & Curcuma longa (Gurati) \\
\hline & Hornstedia & Hornstedia scottiana (Goobe) \\
\hline & Kaempferia & Kaempferia galanga (Bataka) \\
\hline & Zingiber & Zingiber officinale (Goraka) \\
\hline \multirow[t]{3}{*}{ Malvaceae } & Abelmoschus & Abelmoschus manihot (Botaraa / Gedi) \\
\hline & Gossypium & Gossypium hirsutum (Daong kapas) \\
\hline & Hibiscus & Hibiscus rosa-sinensis (Ubo-ubo), Hibiscus tiliaceus (Daong baru) \\
\hline \multirow[t]{4}{*}{ Solanaceae } & Capsicum & Capsicum annum (Rica gufu) \\
\hline & Datura & Datura metel (Kacubu) \\
\hline & Physalis & Physalis angulata (Igo-igono) \\
\hline & Solanum & Solanum carolinensis (Ohulele) \\
\hline \multirow{3}{*}{ Arecaceae } & Areca & Areca catechu (Mokuru) \\
\hline & Cocos & Cocos nucifera (Bua kalapa kacil) \\
\hline & Metroxylon & Metroxylon sagu (Mofafa) \\
\hline \multirow[t]{3}{*}{ Lamiaceae } & Orthosipon & Orthosipon stamineus (Kumis kucing) \\
\hline & Plectranthus & Plectranthus scutellarioides (Daong mayana) \\
\hline & Vitex & Vitex coffasus (Gofasa) \\
\hline \multirow[t]{2}{*}{ Acanthaceae } & Graptophyllum & Graptophyllum pictum (Leleko) \\
\hline & Justisia & Justisia gendarussa (Roringohana) \\
\hline \multirow[t]{2}{*}{ Anacardiaceae } & Anacardium & Anacardium occidentale (Batang bua yakis) \\
\hline & Gluta & Gluta renghas (Hatobu) \\
\hline Annonaceae & Annona & Annona muricata (Kalawada) \\
\hline Apocynaceae & Alstonia & Alstonia scholaris (Pohong hange) \\
\hline Araliaceae & Polyscias & Polyscias scutellaria (Daong deri-deri) \\
\hline \multirow[t]{2}{*}{ Asteraceae } & Blumea & Blumea balsamifera (Totabako) \\
\hline & Chromolaena & Chromolaena odorata (Pitpot maba) \\
\hline Balsaminaceae & Impatiens & Impatiens balsamina (Guabebe) \\
\hline Bombacaceae & Ceiba & Ceiba petandra (Kailupa) \\
\hline Burseraceae & Canarium & Canarium amboinense (Kanari/Niara) \\
\hline Caesalpiniaceae & Senna & Senna alata (Gohobaa) \\
\hline Capparaceae & Cleome & Cleome rutidospermae (Rumpu mata) \\
\hline Caricaceae & Carica & Carica sp. (Tapaya) \\
\hline \multirow[t]{2}{*}{ Convolvulaceae } & Iротоеа & Ipomoea pes-caprae (Loloro) \\
\hline & Merremia & Merremia peltata (Tali kuget) \\
\hline Crassulaceae & Bryophyllum & Bryophyllum pinnatum (Mamata) \\
\hline Cucurbitaceae & Momordica & Momordica charantia (Pupare) \\
\hline Fabaceae & Sesbania & Sesbania grandiflora (Kayu Tur) \\
\hline Gnetaceae & Gnetum & Gnetum gnemon (Rukiti/Ganemo) \\
\hline Lauraceae & Persea & Persea americana (Daong alpokat) \\
\hline Leguminosae & Instia & Instia bijuga (Kayu besi /dowora) \\
\hline Marantaceae & Donax & Donax canniformis (Moa/Obiyawa) \\
\hline \multirow[t]{2}{*}{ Meliaceae } & Lansium & Lansium domesticum (Pohong oluka makai) \\
\hline & Xylocarpus & Xylocarpus granatum (Pohong kira-kira) \\
\hline \multirow[t]{2}{*}{ Moraceae } & Artocarpus & Artocarpus heterophyllus (Tuada) \\
\hline & Ficus & Ficus septica (Bobuluturu) \\
\hline Musaceae & Musa & Musa acuminata (Pisang capatu) \\
\hline Myristicaceae & Myristica & Myristica fragrans (Pala) \\
\hline \multirow[t]{2}{*}{ Myrtaceae } & Psidium & Psidium guajava (Gowaya) \\
\hline & Syzygium & Syzygium aromaticum (Cengke) \\
\hline Passifloraceae & Passiflora & Passiflora foetida (O’bua Puti) \\
\hline Phyllanthaceae & Phyllanthus & Phyllanthus reticulatus (Blakang babiji) \\
\hline \multirow[t]{2}{*}{ Piperaceae } & Peperomia & Peperomia sp. (Rumpu nona) \\
\hline & Piper & Piper betle (Bidoho) \\
\hline Poaceae & Imperata & Imperata cylindrica (Ohungume) \\
\hline & Saccarum & Saccarum officinarum (Tobo) \\
\hline Rhizophoraceae & Rhizopora & Rhizopora mangle (Kayu Soki) \\
\hline Rubiaceae & Morinda & Morinda citrifolia (Daong komene) \\
\hline Rutaceae & Citrus & Citrus aurantiifolia (Lemong nipis) \\
\hline & & Citrus microcarpa (Lemong cui) \\
\hline Smilacacea & Smilax & Smilax sp. (Ngabao) \\
\hline Sterculiaceae & Theobrema & Theobrema cacao (Pohong soklat) \\
\hline $\begin{array}{l}\text { Tidak } \\
\text { teridentifikasi }\end{array}$ & $\begin{array}{l}\text { Tidak } \\
\text { teridentifikasi }\end{array}$ & Spesies 1 (Hamangau) \\
\hline
\end{tabular}


Tabel 2. Nama jenis tumbuhan yang digunakan sebagai bahan obat tunggal atau ramuan oleh Suku Togutil

\begin{tabular}{ll}
\hline Kategori penggunaan/jenis penyakit & \\
\hline & Ramuan \\
\hline Perawatan Pra \& Pasca Melahirkan & Ramuan 1 \\
& Abelmoschus manihot \\
& Hibiscus rosa-sinensis \\
& Ramuan 2 \\
& Hibiscus tiliaceus \\
& Zingiber officinale \\
& Citrus aurantifolia \\
& Ramuan 3 \\
& Syzygium aromaticum Myristica \\
& fragrans \\
& Zingiber officinale
\end{tabular}

Penyakit kelamin

Bisul

Darah tinggi

Flu-Masuk angin

Luka terbuka

Maag

Ambeien

Hernia

Imperata cylindrica

Areca catechu

Keracunan

Mencret

Sakit kulit

TBC

Batuk

Berak darah

Cacar air

Campak

Cedera tulang

Gagal ginjal

Gangguan haid

Gangguan kesuburan (Infertilitas)

Gangguan vitalitas

Herpes

Kecacingan

Kencing manis

Malaria

Pegel (Capek)

Perawatan bayi

Sakit gigi-mulut

Sakit kuning

Sakit mata

Sakit telinga

Sembelit

Bahan obat

Tunggal

Gluta renghas

Hamangau (Spesies 1)

Blumea balsamifera

Sesbania grandiflora

Bryophyllum pinnatum

Canarium amboinense

Rhizopora mangle

Bryophyllum pinnatum

Ceiba petandra

Gossypium hirsutum

Jatropha curcas

Piper betle.

Hamangau (Spesies 1)

Gluta renghas

Gnetum gnemon

Theobroma cacao

Smilax sp

Impatiens balsamina

Saccarum officinarum

Persea americana

Peperomia sp.

Curcuma longa

Kaempferia galanga

Cleome rutidospermae

Musa acuminata

Donax camnaeformis

Citrus microcarpa

Graptophyllum pictum

Morinda citrifolia

Chromolaena odorata

Ipomoea pes-caprae

Mallotus peltatus

Polyscias scutellaria

Euphorbia tirucalli

Alstonia scholaris

Psidium guajava

Artocarpus heterophyllus

Senna alata

Alpinia galanga

Instia bijuga

Myristica fragrans

Plectranthus scutellariorides

Curcuma longa

Merremia peltata

Annona muricata

Annona muricata

Zingiber officinale

Phyllanthus reticulatus

Orthosipon stamineus

Passiflora foetida

Solanum carolinensis

Metroxylon sagu

Carica sp.

Xylocarpus granatum

Lansium demosticum

Phyllanthus reticulatus

Datura metel

Areca catechu

Physalis angulata

Vitex coffasus

Euphorbia sp.

Euphorbia heterophylla

Momordica charantia 
Tabel 2. Lanjutan

\begin{tabular}{|c|c|c|}
\hline Kategori penggunaan/jenis penyakit & & \\
\hline & Ramuan & Tunggal \\
\hline $\begin{array}{l}\text { Tumor/Kanker } \\
\text { Lain-lain* } \\
\text { Mangi (radang mulut pada bayi) } \\
\text { Manikam } \\
\text { Step (demam) padaanak } \\
\text { Mata ikan (kutil) pada jari kaki dan } \\
\text { tangan }\end{array}$ & & $\begin{array}{l}\text { Justisia gendarussa } \\
\text { Anacardium occidentale } \\
\text { Cocos nucifera } \\
\text { Capsicum annum } \\
\text { Ficus septica } \\
\text { Hornstedia scottiana } \\
\text { Impatiens balsamina }\end{array}$ \\
\hline
\end{tabular}

Lain-lain * adalah jenis penyakit yang tidak memiliki istilah baku menurut RISTOJA

obat(Gambar 1). Bahan obat dari kulit batang dan buah menggunakan masing-masing 7 jenis TO, batang 5 jenis TO, dan rimpang 3 jenis TO. Bahan obat dari akar, cabang muda, dan biji hanya diambil masing-masing dari 1 jenis TO. Jenis tumbuhan yang dimanfaatkan seluruh bagiannya yakni Phyllanthus reticulatus yang dimanfaatkan untuk mengobati penyakit gagal ginjal.

Cara mengaplikasikan yang paling umum adalah dioleskan (42 jenis), kemudian berturut-turut secara oral ( 25 jenis), diteteskan ( 2 jenis), dan hanya 1 jenis yang dimasukkan ke rongga hidung (nasal) (Gambar 2).

NilaiKepentinganBudaya. Jenis-jenistumbuhan obatyang dimanfaatkan suku Togutil memilikinilaikepentingan budaya(ICS) berkisar dari 2 sampai 24. Nilai ICS dengankategori tinggi (17-24) dimiliki oleh 15 jenis tumbuhan,antara lain hatobu (Gluta renghas) dan hamangau (spesies1) (Tabel 3). Jenis tumbuhan obat penting lainnya bagisuku Togutil adalah spesies 1 (hamangau), merupakanbahan obat yang dibutuhkan dalam setiap pengobatanpasca melahirkan dan penyakit keputihan pada wanita.

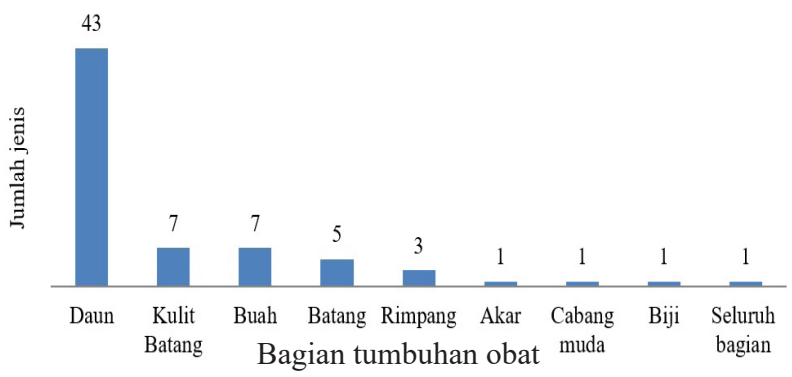

Gambar 1. Jumlah jenis tumbuhan obat Suku Togutil yang dikategorikan berdasarkan bagian yang dimanfaatkan

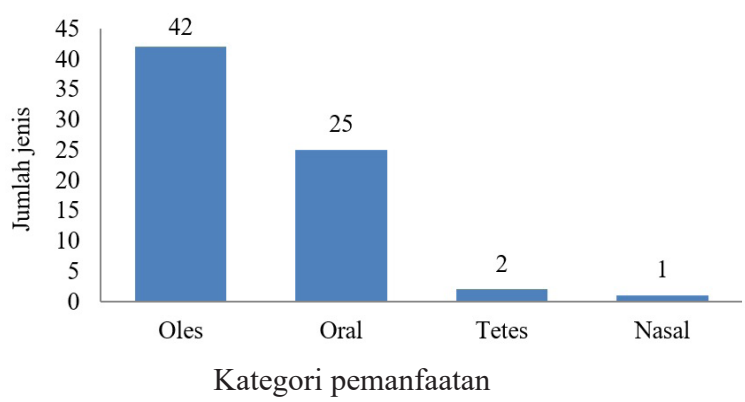

Gambar 2. Jumlah jenis tumbuhan obat Suku Togutil yang dikategorikan berdasarkan cara pemanfaatannya
Oleh karena itu, hamangau juga dikenal dengan nama kayu raja, karena khasiat dan kegunaannya sangat diperlukan oleh masyarakat Togutil.

Terdapat 39 jenis tumbuhan obat yang memiliki nilai ICS kategori rendah (lebih kecil dari 6). Jenis-jenis tumbuhan ini umumnya digunakan sebagai tumbuhan obat utama tunggal dan tumbuhan obat pengganti. Jenis Xylocarpus granatum salah satu TO yang dimanfaatkan sebagai bahan obat utama untuk penyakit diabetes, tetapi jenis TO ini memiliki nilai intensitas penggunaan yang rendah.Jenis tumbuhan Citrus microcarpa yang manfaatkan sebagai obat anti tetanus (Tabel 3).

Tabel 3. Nilai kepentingan budaya jenis-jenis tumbuhan obat berdasarkan nilai kualitas, intensitas, dan eksklusivitas yang diberikan oleh Suku Togutil

\begin{tabular}{ll}
\hline Kategori & Jenis tumbuhan \\
\hline Tinggi Abelmoschus manihot, Blumea balsamifera,
\end{tabular}

(17-24) Cleome rutidospermae, Euphorbia heterophylla, Gluta renghas, Gossypium hirsutum, Graptophyllum pictum, Jatropha curcas, Lansium demosticum, Physalis angulata, Plectranthusscutellarioides, Psidium guajava, Sesbania grandiflora, Sedang Smilax sp. Spesies 1

(9-16) Areca catechu, Bryophyllum pinnatum, Canarium amboinense, Carica sp., Curcuma longa, Euphorbia tirucalli, Hibiscus rosa-sinensis, Hibiscus tiliaceus, Impatiens balsamina, Imperata cylindrica, Merremia peltata, Musa acuminata, Phyllanthus reticulatus, Piperomia sp., Syzygium aromaticum

Rendah Alpinia galanga, Alstonia scholaris, $(<8) \quad$ Anacardium occidentale, Annona muricata, Capsicum annum, Citrus aurantifolia, Citrus microcarpa, Cocosnucifera,Datura metel, Donax canniformis, Euphorbia sp., Ficus septica, Gnetum gnemon, Hornstedia scottiana, Instia bijuga, Ipomoea pes-caprae, Justisia gendarussa, Kaempferia galanga, Mallotus peltatus, Metroxylon sagu, Momordica charantia, Morinda citrifolia, Myristica fragrance Orthosipon stamineus, Passiflora foetida Persea americana, Piper betle, Polyscias scutellaria, Rhizopora mangle,Saccarum officinarum, Senna alata, Solanum carolinensis, Theobrema cacao, Vitex coffasus, Xylocarpus granatum, Zingiber officinale 


\section{PEMBAHASAN}

Tiga famili ini, Euphorbiaceae, Zingiberaceae, dan Malvaceae, memiliki paling banyak jenis-jenis yang dimanfaatkan sebagai tumbuhan obat oleh Suku Togutil. Penelitian Mais et al. (2018) pada etnis Sahu dan Loloda Halmahera Barat menyebutkan bahwa famili Euphorbiaceae, Zingiberaceae, dan Malvaceae merupakan famili dengan jumlah jenis tumbuhan paling banyak yang dimanfaatkan sebagai tumbuhan obat dibandingkan dengan famili yang lain. Tumbuhan obat sebanyak 69 jenis yang dikenal oleh suku Togutil lebih sedikit dibandingkan dengan jumlah tumbuhan obat yang dikenal oleh 4 suku lainnya yang ada di Pulau Halmahera yaitu suku Galela memiliki 234 jenis, Gebe 196 jenis, Makian 182 jenis, dan Patani 203 jenis (Ristoja 2017).

Sebagian besar tumbuhan obat hanya digunakan dalam pengobatan satu jenis penyakit, dan beberapa tumbuhan digunakan untuk mengobati beberapa penyakit (Tabel 2). Guabebe (Impatiens balsamina) digunakan untuk mengobati dua jenis penyakit, yaitu bisul dan penyakit mata ikan. Hatobu (Gluta renghas) digunakan untuk mengobati penyakit kelamin dan perawatan pra dan pasca melahirkan, mamata (Bryophyllum pinnatum) digunakan untuk mengobati demam dan perawatan pra dan pasca melahirkan, goraka (Zingiber officinale) dimanfaatkan untuk mengobati cedera tulang dan perawatan pra dan pasca melahirkan, gurati (Curcuma longa) dimanfaatkan untuk mengobati penyakit flu dan batuk. Penelitian Wati et al. (2017) melaporkan bahwa C. longa memiliki kandungan senyawa metabolit sekunder berupa triterpenoid, flavonoid dan senyawa kurkumin yang aktif sebagai antikanker leukimia. Annona muricata (kalawada) oleh masyarakat Togutil dimanfaatkan untuk mengobati penyakit campak dan cacar air. Berdasarkan (Ristoja 2017), dilaporkan bahwa terdapat 10 jenis penyakit terbanyak yang dapat diobati oleh etnis lain di Maluku Utara yaitu, penyakit luka dalam, sakit telinga, stroke, perawatan kecantikan,kurang darah, batuk, kurang nafsu makan, perawatan pra dan pasca melahirkan,kecacingan dan penyakit magis (sihir).

Daun merupakan bagian tumbuhan yang paling sering dimanfaatkan sebagai obat oleh Suku Togutil. Sebanyak 43 jenis tumbuhan obat Suku Togutil dimanfaatkan daunnya. Daun sebagai bagian tumbuhan yang paling sering dimanfaatkan untuk obat juga dilaporkan pada kelompok masyarakat lain di Indonesia, seperti hasil penelitian Salsabila et al. (2014) pada masyarakat dusun Palutungan, Gunung Cermai Jawa Barat. Seringkali kandungan bahan aktif pada daun lebih tinggi dari bagian tumbuhan lainnya. Penelitian Pambudi et al. (2014) melaporkan bahwa pada bagian daun tanaman anting-anting lebih banyak mengandung senyawa flavonoid yang berfungsi sebagai antioksidan dan antimikroba dibandingkan bagian lainnya.
Berdasarkan pengalaman Suku Togutil, penanganan jenis-jenis penyakit yang dikenali dilakukan dengan memanfaatkan bahan tumbuhan obat tradisional sebagai obat oles, obat oral, obat tetes dan obat nasal. Obat oles yang digunakan adalah obat luar yang umumnya berfungsi untuk mengobati luka sayatan, luka infeksi, penyakit kulit seperti kudis dan panu, bisul, obat demam, perawatan pasca melahirkan, cedera tulang, ambeien, maupun hernia. Obat oral merupakan obat berupa ramuan yang diminum untuk mengobati penyakit seperti batu ginjal, flu, maag, sembelit, gangguan menstruasi, batuk darah (TBC), malaria, impoten, hipertensi, tumor, penyakit kelamin (keputihan, kencing nanah), berak darah, diabetes, dan kanker. Obat tetes merupakan obat yang digunakan untuk mengobati infeksi maupun iritasi pada mata dan telinga. Menurut Ristoja (2015) obat tetes digunakan untuk mengobati mata kering dan kemerahan, akibat debu dan benda asing, mata merah diikuti mata berair atau berlendir dan nyeri atau kelainan pada telinga meliputi congek, pendengaran berkurang, tuli, berdenging, kemasukan benda asing. Obat nasal merupakan obat yang dihirup melalui hidung yang digunakan masyarakat Togutil untuk mengobati flu.

Jenis-jenis tumbuhan yang memiliki ICS kategori tinggi untuk Suku Togutil adalah Gluta renghas dan hamangau. Hasil uji fitokimia terhadap tumbuhan G. renghas menunjukan adanya kandungan senyawa metabolik sekunder yaitu, alkaloid, flavonoid, dan terpenoid (Nursal et al. 2016). Senyawa alkaloid diketahui memiliki efek farmakologi dan sering dimanfaatkan sebagai bahan obat-obatan. Pada penelitian lain yang dilakukan terhadap masyarakat Dayak Bakumpai menyebutkan bahwa jenis $G$. renghas termasuk kategori tumbuhan beracun, tumbuhan ini digunakan sebagai bahan racun mata panah ketika akan berburu. Selain itu, getah tumbuhan ini bisa mengakibatkan iritasi kulit, gatalgatal hingga melepuh (Ilmi et al. 2015). Menariknya pada masyarakat Togutil, jenis tumbuhan ini dimanfaatkan untuk mengobati penyakit kelamin (keputihan) dan perawatan pasca melahirkan.

Tumbuhan hamangau selain dimanfaatkan sebagai tumbuhan obat juga dijadikan sebagai pohon keramat (ritual) yang hanya boleh diambil oleh dukun adat (informan kunci), hal lain yang menyebabkan tumbuhan ini tidak dapat diidentifikasi nama ilmiahnya adalah karena pada saat pengambilan sampel tumbuhan, bagian yang diambil oleh informan kunci adalah kulit batang dari pohon tersebut. Sehingga data yang diperoleh sangat minim dan tidak dpat dijadikan patokan untuk mengidentifikasi tumbuhan tersebut. Penelitian Niapele (2014) menyatakan bahwa masyarakat adat Togutil percaya setiap tumbuhan yang tumbuh di sekitar manusia memiliki jiwa. Oleh karena itu, setiap pemanfaatan tumbuhan obat harus dilakukan dengan baik dan terkadang dilakukan ritual khusus oleh dukun adat 
(gomatere). Hal ini juga ditemukan pada saat akan mengambil tumbuhan obat hamangau.

Jenis $C$. microcarpa memiliki kandungan vitamin C yang dapat berfungsi sebagai senyawa aktif antimikroba yang dapat menghambat pertumbuhan bakteri yang berkembang pada daerah yang terinfeksi (Arabit et al. 2017). Namun tanaman obat ini memiliki ICS kategori rendah bagi Suku Togutil. Pada suku Togutil tumbuhan obat $C$. microcarpa ini hanya digunakan sebagai bahan pengobatan anti tetanus, sementara kasus tetanus jarang dijumpai sehingga intensitas pengunaan $C$. microcarpa sebagai bahan obat juga jarang digunakan.

\section{KESIMPULAN}

Masyarakat Suku Togutil mengenal 69 jenis yang termasuk 40 famili tumbuhan yang dimanfaatkan dalam pengobatan tradisional. Bagian tumbuhan yang paling banyak dimanfaatkan adalah bagian daunnya (43 jenis). Pemanfaatan tumbuhan obat tersebut lazim dilakukan dengan cara dioleskan (42 jenis), dikonsumsi secara oral (25 jenis), diteteskan (2 jenis) serta digunakan secara nasal (1 jenis). Jenis-jenis tumbuhan obat Suku Togutil memiliki ICS berkisar 24 hingga 2, Gluta renghas yang dimanfaatkan sebagai bahan obat untuk perawatan pasca melahirkan merupakan jenis tumbuhan obat dengan nilai ICS tertinggi bagi Suku Togutil.

\section{UCAPAN TERIMA KASIH}

Ucapan Terima kasih dan penghargaan yang setinggi-tingginya penulis haturkan kepada Ibu Dr Nunik Sri Ariyanti MSi, Prof (Ris) Dr Ir Eko Baroto Walujo MSc, dan Dr Ir Dorly MSi selaku pembimbing. Di samping itu, penghargaan penulis sampaikan kepada Bapak Asmin selaku Kapita Suku Togutil di Halmahera Timur, keluarga besar Suku Togutil di Daerah Penyangga Taman Nasional Aketajawe Lolobata, serta Bapak Ibrahim Wael dan keluarga yang ramah dalam membantu penulis selama proses pengumpulan data.

\section{DAFTAR PUSTAKA}

Arabit PMT et al. 2017. The immunomodulatory effect of Citrus microcarpa peel in Macrobrachium rosenbergii challenged with Vibrio alginolyticus. AACL Bioflux 10:652-662.

Ilmi $\mathrm{J}$ et al. 2015. Inventarisasi dan pemanfaatan tumbuhan beracun oleh masyarakat Dayak Bakumpai di desa Simpang Arja Kecamatan Rantau Badauh Kabupaten Barito Kuala. Wahana-Bio 8:93-114.

Karim KA, et al. 2006. Pemanfaatan keanekaragaman genetik tumbuhan oleh masyarakat Togutil di sekitar Taman Nasional Aketajawe Lolobata. Media Konserv 11:1-12.

Mais $\mathrm{M}$ et al. 2018. Pemanfaatan tumbuhan obat oleh etnis Sahu dan Loloda di Halmahera Barat Maluku Utara. MIPA UNSRAT 7:8-11.

Niapele S. 2014. Bentuk pengelolaan hutan dengan kearifan lokal masyarakat adat Togutil. Agrikan 6:62-72.
Noorcahyati. 2012. Tumbuhan Berkhasiat Obat Etnis Asli Kalimantan. Samboja: Balai Penelitian Teknologi Konservasi Sumber Daya Alam. Badan Litbang Kementrian Kehutanan.

Nurrani L, Tabba S. 2013. Persepsi dan tingkat ketergantungan masyarakat terhadap sumberdaya alam Taman Nasional Aketajawe Lolobata di Provinsi Maluku Utara. Penelitian Sos Ekon Kehut 10:61-73.

Nursal et al. 2016. Uji toksisitas ekstrak kulit batang rengas (Gluta Renghas) terhadap larva udang. Artemia salina Biogenesis 13:11-18.

Pambudi A et al. Identifikasi bioaktif golongan flavonoid tanaman anting-anting (Acalypa indica L.). Al-Azhar Indones 2:178187.

Rahman SA. 2013. Kajian etnomedisin pada orang Togutil di Halmahera: sistem personalistik dan naturalistik [tesis]. Yogyakarta: Universitas Gajah Mada.

[Ristoja] Riset Tumbuhan Obat dan Jamu. 2015. Pedoman pengumpulan data. Dalam Riset Khusus Eksplorasi Pengetahuan Lokal Etnomedisin dan Tumbuhan Obat Berbasis Komunitas di Indonesia. Jakarta: Kemenkes RI.

[Ristoja]Riset Tumbuhan Obat dan Jamu. 2017. Ramuan pengobatan. Dalam Eksplorasi Pengetahuan Lokal Etnomedisin dan Tumbuhan Obat Berbasis Komunitas di Indonesia, Provinsi Maluku Utara. Jakarta: Kemenkes RI. Hal. 33-38

Salsabila PP, Zuhud EAM, Siswoyo. 2014. Pemanfaatan tumbuhan pangan dan obat oleh masyarakat di dusun Palutungan, desa Cisantana, sekitar Taman Nasional Gunung Ciremai. Media Konserv 19:146-153

Wati I et al. 2017.Pengaruh konsentrasi pelarut, waktu ekstraksi, dan nisbah bahan baku dengan pelarut terhadap ekstraksi kunyit kuning (Curcuma longa L ). ITEKIMA 2:52-60. 